\title{
Youth Culture and Political Participation: The Case of Media Framing of Youth Protest at Ankara University in Turkey ${ }^{1}$
}

Kenan Demirci

Research Assistant, Ankara University kdemirci06@gmail.com

\section{Doi:10.5901/mjss.2013.v4n3p339}

\section{Abstract}

In this study, I want to focus on the framing effect that the media has on public opinion. Political participation has become very popular in recent years. Youth participation, in particular, has gained importance because politicians pay more attention to the participation of the youth. Merely, the youth's role is restricted to voting. Moreover, the media plays an important role in shaping the people's attitude toward youth participation. I studied print media news reports on a student protest held at the Ankara University's Faculty of Political Science on 8 December 2010 in Turkey. The students were protesting against a member of the Grand National Assembly of Turkey, Burhan Kuzu; some students even threw eggs at him. The press paid great attention to this event. For this purpose, I have employed the framing effect technique in concert with critical discourse analysis to analyse the two most popular Zaman and Hürriyet news reports in Turkey for a week in December 2010 in an attempt to understand the relationship between youth participation and the framing effect of the media. I wish to study the framing effect as a descriptive tool. In brief, these reports declared the protesters enemies of the public. This narrow view of participation is not suitable for a democratic improvement.

Keywords: Youth, Participation, Apathy, Democracy in Turkey, Media

\section{Introduction}

This study is an examination of framing practised by the print media in Turkey with respect to the political protests of the youth. Political protests of the youth comprise a very widespread form of opposition in modern democracies. When examining the Turkish democracy closely, one can see that youth opposition is not seen as a legal method of engaging in politics. There are many forms of legislation prohibiting the participation of youth in politics in Turkey. In Turkey, one particular way of engaging in politics is voting. My assumption is that the media support the political system by encouraging political apathy among the youth. I studied print media news reports concerning a student protest held by Ankara University's Political Science Faculty on 8 December 2010. For this purpose, I have employed the framing effect technique to analyse the two most popular news reports in Turkey during one week in December 2010 in an attempt to understand the relationship between youth participation and the framing effect of the media.

\subsection{Democratic Participation in Turkey}

In a pluralistic democracy one of the main foundations is stability. In every condition, a system must be stable, because if a system is not stable, democracy cannot function. To provide stability, a system must tolerate an elitist system of representation. Because the masses are not necessary for the management function, their function only confirms the political elites who have management skills. If the masses were on the political stage, the system would not be suitable. The masses cannot know what are suitable requirements for the system. Hence, the masses must be deterred from becoming part of the decision-making process. Macpherson (1979) noted:

The main stipulations of this model are, first, that democracy is simply a mechanism for choosing and authorizing governments, not a kind of society nor a set of moral ends; and second, that the mechanism consist of a competition between two or more self-chosen sets of politicians (elites), arrayed in political parties, for the votes which will entitle them to rule until the next election. The voter's role is not to decide political issues and then choose representatives who will carry out those decisions: it is rather to choose the men who will do the deciding (p.78).

${ }^{1}$ A basic version of this paper is presented at the International Communication Student Congress (Icsc) 28-29 March 2013 Maltepe University 
As a consequence of these processes, the masses are alienated from the political decision-making process. This creates a sense of apathy among the masses. Apathy is suitable for the political system because citizens are customers, and political parties are entrepreneur in the political market. Therefore, citizens only want to achieve their individual goals in the market, they "should surely not expect as much return as those who are more active" (Macpherson, 1979:87). I think that this differentiation is comprised of a large division between pluralistic democracy and participative democracy. Important researchers of the pluralistic model promoted apathy to gain stability in the system (Jones, 1954; Lipset, 1960; Berelson, 1986) but the researchers using the critical model resist the apathy among the masses (Pateman, 1970; Macpherson, 1979). For the critical theorists of democracy, if masses do not participate in the decision-making process, democracy cannot work. Especially in the modern capitalist market conditions, issues about health, education, and national security are more complicated than previously. Hence, it is too difficult for an ordinary citizen following these issues. As a consequence, people follow important issues via the media. The decision-making process is distant from an ordinary citizen (Offe, 2011). However, if we define democracy as "the rule of the people" (Pateman, 1970:2); we will see that apathy is not suitable for a democratic culture.

The distinction between the two approaches of apathy is important for my study, because a pluralistic view of democracy and apathy can be seen in the Turkish political system. Democracy is interpreted with this narrow definition in Turkey (Doğanay, 2002). Participation is seen as voting and the other methods of participation are alien to this culture. Stability is the main purpose of democratic compatibly with the pluralist elitist model of democracy. An assumption of a pluralist elitist model merges with the specific properties of Turkey's history of democracy. If we follow Doğanay (2007), we can talk about three main categories of properties in Turkish democracy.

1. "Since the late eighteenth century, the political elites have played a significant role in Turkish politics by connecting Turkey's future to the west (...) The role of citizens has largely been disregarded, and democratization is, therefore, not the conclusion of social transformation realized by citizens themselves" (390). As we see, Turkish democracy has a well-grounded relationship with the political elites in Turkey. Hence, the role of citizens is seen as voting.

2. The military has a significant role in the Turkish democracy. The founder of the republic, Mustafa Kemal Atatürk and his friends, were soldiers. Therefore, the military has a significant role in Turkish democracy. Military elites think that the role of the army is protecting the democracy in all circumstances. When they think that there is a great threat against the democracy, they do not hesitate to appeal to the coup. Turkey has had three coups: 1960, 1971 and 1980 (391).

3. The last category is "specific circumstances of Turkey". Traditionally, the Turkish military and political elites think that Turkey has internal and external enemies. Therefore, if we want to protect democracy, we must move carefully (391).

The specific properties of democracy affect the view of democracy. The acts of governments are properly with these properties. Stability is the main objective associated with national unity and solidarity. Youth movements, protests, and other alternative methods of participation are affected by this narrow understanding of democracy. The notion of stability is the main tool with the objective of protecting democracy. Herein, in Turkey, political participation of youth can be seen as an activity of university students historically. Hence, legislation, judiciary, and the law of higher education are compatible with the objective of repressing university students (Uysal, 2001).

In brief, political participation is almost restricted to voting, especially since the 1982 Constitution of Turkey restricted citizen mobilization. For example, relations between civil society and political parties are restricted. Thus, in Turkey, citizens can't mobilize; they can only vote. At this point, my view is that the apathy of the youth, in particular, is affirmed by the political system itself. The youth's role is restricted to voting. Moreover, the media plays an important role in shaping the people's attitudes toward youth participation.

\subsection{Youth Movements and Media In Turkey}

The pluralistic elitist model gives an important role to the media in a democratic country. Liberal democracy is defined as a process of representation and political campaigns are very important in the overall democratic structure. Hence, reaching information about political parties and political elites is very important. The main tool of enlightenment in crowded and complicated countries is media. Therefore, in a democratic country, the media's main function is to keep the people informed. This view was criticized through research that focused on media ownership, media logic, the strategic use of media technologies, and so on. In this study, I want to focus on the framing effect that the media has on public opinion. I wish to study the framing effect as a descriptive tool. By using the episodic effect, the media can focus on 
particular aspects of the youth's political participation. The media represent political movements of the youth in a negative light, and this is considered a guide to being a 'normal' student.

I assume that media framing of youth culture is shaped by the view of narrow democracy, which seems that citizen participation is equal to voting. Why is the framing role of media important for youth movements? This is because media has an important role in the political process. Media forms move away from an area of different political views. Thus, media have corruptive effects on the cognitive capacities of citizens. Blumler (1990) called this situation the "modern publicity process". The modern publicity process is a struggle to influence key political events and issues. First, there are results; basically, politic actors get more resources and energy for their media strategies. Second, pressure group activities will be more media-centric. Third, political decisions will be more media mediated. Fourth, personalization dominates politics rather than difficult issues. Finally, media will determine the rules of the modern publicity game. In brief, media are redefined by politics and its content.

Appropriately, the framing role of media about youth movements has been examined in a number of studies (Halloran et al., 1970; Gitlin, 1980; Baylor, 1996; Benford and Snow, 2000). However, in Turkey there are few studies about youth movements (Uysal, 2001;Köker and Doğanay, 2004). I think this situation is compatible with the democratic sense of youth participation. In Turkey, the main idea about the university students is "their main duty is study, demonstration and the other participation forms are not proper for a student". I claim that news framing is compatible with these ideas.

I analyse episodic framing practised by the print media in Turkey with respect to the political protests of the youth. My assumption is that the media supports the political system by encouraging political apathy among the youth. In Turkey, the average age of participants of movements is between 18 and 21 years (university students). The media label the young people who participate in social movements as 'guilty'. I studied print media news reports on a student protest held by Ankara University's Faculty of Political Science on 8 December 2010. The students were protesting against a member of the Grand National Assembly of Turkey, Burhan Kuzu; some students even threw eggs at him. The press paid great attention to this event. For this purpose, I have employed the framing effect technique in concert with critical discourse analysis to analyse the two most popular news reports in Turkey for one week during December 2010 in an attempt to understand the relationship between youth participation and the framing effect of the media. I want to find constructed meanings about youth participation in the print media.

\section{Method}

I analyse framing practised in concert with discourse analyses by the print media in Turkey with respect to the political protests of the youth. The framing technique has been used widely in youth movement analyses. Benford and Snow (2000) explain:

The recent proliferation of scholarship on collective action frames and framing process in relation to social movements indicate that framing processes have come to be regarded, alongside resource mobilization and political opportunity processes, as a central dynamic in understanding the character and course of social movements (611).

I follow Altheide (1996) in my study, and attempt to understand media texts associated with frame and discourse analyses. He argued that, frame, theme, and discourse are similar notions to analyse media texts. He explained:

I have found it useful to use the concepts of frame and discourse in studying news report. As I have stressed, frames are a kind of 'super theme'. Although there are subtle distinctions, they can be closely joined when examining documents: Frames and discourse help us appreciate this relationship, even though these concepts are also related. Discourse refers to the parameters of relevant meaning that one uses to talk about things. Frame refers to the particular perspective one uses to bracket or mark off something as one thing rather than another. Meaning and language are implicated in both. We can simply say that discourse and frame work together to suggest a taken-for-granted perspective for how one might approach the problem (31).

It is important to understand what the frame is at this point. I accept the frames as an interpretation process that affected public opinion. It refers to "behavioural or attitudinal outcomes that are not due to differences in what is being communicated, but rather to variations in how a given piece of information is being presented (or framed) in public discourse" (Scheufele and lyengar, 2012: 1). As we follow Baylor (1996), we can say that there are some structural news biases affecting media framing (242). I think that stability of the system is the most important structural news bias.

News bias about stability affects the discourse of newspapers. I try to analyse this effect on the cognitive dimension of discourse. It is important to understand media discourse, because people construct their social reality about 
ideas, values, and practices (Chilton and Schaffner, 2002: 25). When framing supports stability and refuses alternative political participation, it affects the people's reality about participation.

For this purpose, I want to analyse an example of youth protest in Turkey. I study print media news reports on a student protest held by the Ankara University's Faculty of Political Science on 8 December 2010. I think that the main framing of youth movement news is shaped with the desire of stability. With this idea, apathy is an important tool, and the approach of youth movements is suitable for its consideration. Thus, I want to analyse newspaper reports employing discourse analysis. I want to identify three themes of youth participation compatible with the general tendencies of Turkish democracy. The first category is "ungovernability", the second is "threat of coup", and last is "internal and external enemies of Turkey"

\section{Research}

I analysed two of the most popular newspaper's reports from 8 December 2010 to 31 December 2010. I analysed Zaman and Hürriyet. I chose Zaman as a representative of the Islamist/conservative press and Hürriyet as a representative of the liberal press. I analysed 70 reports in two newspapers.

\begin{tabular}{|c|c|c|}
\hline Newspaper & Number of reports & Percentage \\
\hline Zaman & 39 & 55.7 \\
\hline Hurriyet & 31 & 44.2 \\
\hline Total & 70 & 100 \\
\hline
\end{tabular}

Table 1. Total News About Youth Protest

As we see in Table 1, Zaman has the most number of news reports. The large number of reports taking place in this newspaper is no surprise. Zaman can be defined as a conservative newspaper and it is known for its proximity to the government. Zaman's main purpose can be seen as protecting the government. Hürriyet has a great deal of news about the protest. Hürriyet is known as a liberal/popular newspaper in Turkey. It is possible to say that the news took place in the newspaper because of its interesting aspect. The protest with eggs was interesting for a popular newspaper.

\subsection{Seen the Problem as Ungovernability}

As I mentioned before, Turkish democracy is established by political elites. The citizens' role is not about politics; the only participation for them is voting. Therefore, it is very common to think a protest movement is the consequence of ungovernability. A large number of news media approach this issue as an ungovernability problem. Most of the news forms call for resignation for the dean and rector.

\begin{tabular}{|c|c|c|}
\hline Newspaper & $\begin{array}{c}\text { News About } \\
\text { Call for Resignation }\end{array}$ & $\begin{array}{c}\text { Percentage to Total } \\
\text { Rate }\end{array}$ \\
\hline Zaman & 15 & $38.4 \%$ \\
\hline Hürriyet & 2 & $6.4 \%$ \\
\hline
\end{tabular}

Table 2. Percentage of News About Call For Resignation

As we see in Table 2, Zaman included the reports that "call for resignation". Zaman has a close relationship with the government. It is possible to say that they want to say "there is no government weakness; it is a weakness of management team of university." Student protests are not compatible with the stability of democracy. It must be precluded by the authorities, but the newspaper does not want to blame the government. "Even my dad makes this task better" is an interesting news example. There is little news about the call for resignation of Hürriyet. His is not as close a relationship with the government as that of Zaman. Hence, they do not need to look for another enemy. Their emphasis is that faculty cannot prohibit a student activity. They wish Burhan Kuzu had not come to the university.

We can say that neither newspaper discussed participation in the right way for young people. It is important for them to keep the face of stability in the system. However, the guilty and the victim are changing. For the Zaman, university administrators are guilty, and the victim is Burhan Kuzu. For Hürriyet, the visitor Burhan Kuzu is guilty; the victims were university administrators. Neither newspaper wants to talk about the participation of the youth. 


\subsection{Threat of Coup}

Turkey has had three coups in its history. The recent history of Turkey (the 1980 coup) is particularly important. For security reasons and increasing political protest and violence, the Turkish army seized power in 1980. Student protest was seen as violence and was repressed by the army forces. This event resulted in a great deal of fear for Turkish citizens. Some political elites traditionally called the army "for duty" when the increasing social movements and other issues began to become a threat toward the republic, since 1980 .

\begin{tabular}{|c|c|c|}
\hline Newspaper & $\begin{array}{c}\text { News about the } \\
\text { Threat of a Coup }\end{array}$ & $\begin{array}{c}\text { Percentage to Total } \\
\text { Rate }\end{array}$ \\
\hline Zaman & 10 & $25.6 \%$ \\
\hline Hürriyet & 2 & $6.4 \%$ \\
\hline
\end{tabular}

Table 3. Percentage of News about the Threat of a Coup

The republic of Turkey was established in 1923. Since then, there has been a big struggle between military founder elites and Islamic elites. İslamist elites have gained power in Turkey, especially since 2002 and they do not want to lose their power. If a coup were to occur, power would spread. Therefore, it is possible to say that Islamic and conservative elites in Turkey have a great fear of coup. They interpret youth protest as a tool, which could end with a coup. They want system stability more than anyone. All of the high ranking news in Zaman is about "no one wants to return that darkness". In addition, separation between acceptable students and unacceptable students is important. Most of the students who only study their lessons are acceptable for the system. However, students who act politically are unacceptable students. They can cause a coup and bring the "dark days" back.

Hürriyet is a liberal newspaper in Turkey. They are not afraid of coup as much as Islamist elites are. They want stability, but small student movements are not a big problem. We can assume that their first purpose is to protect the liberal environment, and a little student protest is not dangerous for the system.

\subsection{Internal and External Enemies of Turkey}

Turkey was established after a great war of independence. That is why Turkish political elites have a fear of internal and external enemies in Turkey. To trust and protect the government is a basic tide in Turkish government. Internal enemies such as communist movements or to join a coup are big enemies for the Turkish political system. Hence, every protest against the political elites or the government herself is perceived as a threat. Establishing a relationship between these internal enemies and local movements in Turkey, youth protest and movements are seen as one of these enemies.

\begin{tabular}{|c|c|c|}
\hline & $\begin{array}{c}\text { News About } \\
\text { Call for Resignation }\end{array}$ & $\begin{array}{c}\text { Percentage to Total } \\
\text { Rate }\end{array}$ \\
\hline Zaman & 8 & $20,5 \%$ \\
\hline Hürriyet & 4 & $12,9 \%$ \\
\hline
\end{tabular}

Table 4. Percentage of News About Call for Resignation

Zaman is an Islamist newspaper. It is not surprising that the largest number of reports occur in the newspaper. In news, we can see the Turkish terrorist organization Ergenekon and student groups linking up. The general discourse is "protestors may not be a student", "there is a great pressure on the students from the external groups". Again, there is the same polarization among the acceptable versus unacceptable students. A normal student cannot want to be a part of political protest; they must be the "terrorists" who come from the external world.

Hürriyet has a few reports about the situation at Hürriyet. Avoiding making a link between youth protest and the internal enemies is not a priority of the newspaper. The main reason for this situation is the newspaper's liberalist disposition. They think that a little student protest is not a problem for the whole system.

\section{Conlusion}

The pluralist elitist model of democracy highlights the issue of stability. If a system wants to stay in a stable position, 
policymaking must be the duty of political elites. The role of citizens in this democratic system is restricted to voting. The other participation tool is not suitable for the system's stability in general. Compatibly, the Turkish political system wants stability associated with the security of the State and the other traditional properties. As noted before, youth movements and protests are seen as destructive actions for the stability of the system. Keeping youth movements under control is the duty of the government.

Compatibly, the Zaman newspaper, which has a close relationship with the government, resists student movements. They framed the youth protest as desiring a coup and cooperation with internal enemies. If there is an ungovernability problem it is relevant to the university administrators. The second important point in the reports in Zaman is an effort to create polarization. The world of the youth is divided into two parts: acceptable youth and unacceptable youth. Most of the students are part of the acceptable world; the other side is not crowded but the people staying there are dangerous.

The liberal newspaper Hürriyet handled the project as a little protest movement. They do not see protest as a serious problem for the stability of the system. Their news framing was generally about the problem of the parliamentarian visiting the faculty. He had been warned not to come to the faculty by the police; therefore, he knew the situation before he came to the faculty. The other interesting point in the event is eggs were used in the demonstration. It is a very interesting point. Almost half of the reports mentioned the eggs.

In general two of the newspaper do not presented the movement as a participation act. They look for a guilty for the protest movement. As we know, democracy is not meaningful without citizen participation. And youth protest is a great part of participation process. I think that, this narrow view of participation is not suitable for a democratic improvement. Because if youth apposition is not seen as a legal method, we cannot talk about accountability of the government or other power groups

\section{References}

Altheide, David L. (1996). Qualitative Media Analysis. USA: Sage

Baylor, Tim (1996). Media Framing of Movement Protest: The Case Of American Indian Protes, The Social Science Journal, 33-3, 241255.

Benford, Robert D. And, Snow, David A (2000). Framing Processess and Social Movements: An Overview and Assessment, Annual Review of Sociology, 26, 611-639.

Berelson, B.R., Lazarsfeld P. F., and McPhee W.N (1986). Voting. USA: Chicago University Press

Blumler, Jay G. (1990). Elections The Media and The Modern Publicity Process. In Marhoire Ferguson (Eds.), Public Communication The New Imperatives. London: Sage

Chilton, Paul ve Schaffner, Christina (2002). Introduction. In P. A. Chilton ve C. Schaffner (Eds.), Politics as Text and Talk Analitic Approaches to Political Discourse. Philadelphia: John Benjamins Publishing Company

Doğanay, Ülkü (2003). Demokratik Usuller Üzerine Yeniden Düşünmek. Ankara: Imge

Doğanay, Ülkü (2007), The Turkish Parliament on Democracy, Parliamentary Affairs 60 (3), 388-408.

Gitlin, Todd (2003). The Whole World Is Watching. London: University of California Press

Jones, Morris (1954). In Defence of Apathy: Some Doubts on the Duty to Vote. Political Studies, 2 (1), 25-37.

Köker, Eser and Doğanay, Ülkü (2004). Televizyonda Protesto Görüntüleri: Egemen Haber Söylemlerinde Toplumsal Eylemler. Kültür ve Illetişim, 7 (2), 43-72

Lipset, S. M. (1960). Political Man. Doubleday: Garden City

Macpherson, C. B. (1979). The Life and Times of Liberal Democracy. Oxford: Oxford University Press

Offe, Clause (2011). Crisis and Innovation of Liberal Democracy: Can Deliberation Be Instituonalised?. Czech Sociological Review, 47(3), 447-472.

Pateman, Carole (1970). Participation and Democratic Theory. Cambridge: Cambridge University Press.

Scheufele, Dietram A. And lyengar, Shanto (2012). The State of Framing Research: A Call For New Directions. Unpublished Manuscript, Milano, $3^{\text {rd }}$. International Political Communication and Electoral Behaviour Summer School

Uysal, Ayşen (2001). Devletin Güvenliği ve toplumsal Muhalefet Eylemleri. Birikim, 146, 64-84.

www.zaman.com.tr (February, 7, 2013)

www.hurriyet.com.tr (February, 7, 2013) 